\title{
Recent advances in dead cell clearance during acute lung injury and repair
}

\author{
Patrick M. Noone ${ }^{1, X} \quad$ Sekhar P. Reddy ${ }^{1,2^{*}, X}$ \\ ${ }^{1}$ Department of Pediatrics, College of Medicine, University of Illinois at Chicago, IL 60612, USA \\ ${ }^{2}$ Department of Pathology, College of Medicine, University of Illinois at Chicago, IL 60612, USA \\ ${ }^{\mathrm{x}}$ Equal contributors
}

\begin{abstract}
Acute lung injury (ALI) and acute respiratory distress syndrome (ARDS) are clinical syndromes that cause significant mortality in clinical settings and morbidity among survivors accompanied by huge healthcare costs. Lung-resident cell dysfunction/death and neutrophil alveolitis accompanied by proteinous edema are the main pathological features of ALI/ARDS. While understanding of the mechanisms underlying ALI/ARDS pathogenesis is progressing and potential treatments such as statin therapy, nutritional strategies, and mesenchymal cell therapy are emerging, poor clinical outcomes in ALI/ARDS patients persist. Thus, a better understanding of lung-resident cell death and neutrophil alveolitis and their mitigation and clearance mechanisms may provide new therapeutic strategies to accelerate lung repair and improve outcomes in critically ill patients. Macrophages are required for normal tissue development and homeostasis as well as regulating tissue injury and repair through modulation of inflammation and other cellular processes. While macrophages mediate various functions, here we review recent dead cell clearance (efferocytosis) mechanisms mediated by these immune cells for maintaining tissue homeostasis after infectious and non -infectious lung injury.
\end{abstract}

\section{Keywords}

Acute lung injury, Lung repair, Macrophages, Alveoli, Efferocytosis

\section{Peer Review}

The peer reviewers who approve this article are:

1. Hongguang Nie, Department of Stem Cells and Regenerative Medicine, College of Basic Medical Science, China Medical University, Shenyang, China

Competing interests: No competing interests were disclosed.

2. Narasaiah Kolliputi, University of South Florida, Division of Allergy and Immunology, Department of Internal Medicine and Department of Molecular Medicine, College of Medicine, Tampa, Florida 33612, United States

Competing interests: No competing interests were disclosed. 
*Corresponding author: Sekhar P. Reddy (sreddy03@uic.edu)

Competing interests: The authors declare that they have no competing interests.

Grant information: This work was supported by the National Institutes of Health grants HL136946 and GM124235 (SR).

The funders had no role in study design, data collection and analysis, decision to publish, or preparation of the manuscript.

Copyright: (C) 2021 Reddy SP et al. This is an open access article distributed under the terms of the Creative Commons Attribution License, which permits unrestricted use, distribution, and reproduction in any medium, provided the original work is properly cited.

How to cite this article: Noone PM and Reddy SP. Recent advances in dead cell clearance during acute lung injury and repair. Faculty Reviews 2021 10:(33) https://doi.org/10.12703/r/10-33

Published: 30 Mar 2021, Faculty Reviews 10:(33) https://doi.org/10.12703/r/10-33 


\section{Acute lung injury}

Acute lung injury (ALI) and its most severe form, acute respiratory distress syndrome (ARDS), together affect approximately 200,000 patients per year in the United States alone, with reported mortality rates of about $30-40 \%{ }^{1}$. Oxygen supplementation (hyperoxia) by mechanical ventilation remains the primary therapy used for supporting critically ill patients with ALI/ARDS proven to decrease mortality ${ }^{2}$, but as many as $9-27 \%$ of patients undergoing this therapy contract nosocomial pneumonia, leading to excess morbidity and mortality ${ }^{3}$. Nosocomial pneumonia poses a substantial cost burden ${ }^{4}$ and accounts for approximately $27 \%$ of hospital-borne infections in American ICUs, of which $86 \%$ of cases were associated with mechanical ventilation $^{2}$. Thus, identification of novel mechanisms underlying abnormal lung repair and microbial susceptibility may provide a basis for new therapeutic strategies that can improve clinical outcomes and decrease healthcare costs associated with ALI/ARDS.

Understanding of the mechanisms underlying ALI/ARDS is evolving, but, aside from ventilation, limited therapies of significant clinical benefit are available for intervening in lung injury progression $^{5,6}$. Currently, treatments include statin therapy ${ }^{7}$, nutritional strategies ${ }^{8}$, and mesenchymal cell therapy ${ }^{9,10}$, but persistence of high mortality rates demonstrates their limitations and warrants exploration of alternative approaches ${ }^{5,6}$. Strategies for promoting lung repair that show favorable in vitro and in vivo results include plasma membrane repair via amphiphilic macromolecules ${ }^{11}$, administration of growth factors ${ }^{12}$, selective blockade of matrix metalloproteinases ${ }^{13,14}$, and modulation of proliferation-regulating transcription factors ${ }^{15,16}$. Additionally, gene therapy studies using viral and non-viral vector delivery, gene expression strategies, or enhanced therapeutic targeting offer promising evidence of restoring lung function, clearing inflammation, and enhancing repair mechanisms in vitro and in vivo ${ }^{6}$. However, clinical use of these techniques requires extensive progress to be made in terms of basic science and its translational approach. Perhaps most importantly, there are still immense gaps in our knowledge of molecular targets involved in the pathogenesis of ALI/ARDS. Therefore, better characterization of cellular mechanisms involved in heightened inflammation resolution and repair is necessary to develop novel therapies for ALI/ARDS patients.

Alveolar macrophages (AMФs) account for approximately 95\% of airspace leukocytes ${ }^{17}$. They are major regulators of the lung inflammatory microenvironment and the first line of defense against infectious and non-infectious stimuli $^{18}$. The course of systemic inflammation and progression to ALI/ARDS is heavily dependent on signaling from these cells, and their defective functioning is associated with multiple acute and chronic inflammatory conditions ${ }^{19,20}$. This regulatory capability is in part due to the phagocytic role AMФs play in clearing dead cells from the alveolar space, which facilitates injury resolution and prevents necrosis of apoptotic cells and release of pro-inflammatory mediators ${ }^{21}$. AMФs are highly functionally heterogeneous and phenotypically variable, which allows them to use intracellular signals to switch between pro-inflammatory and anti-inflammatory states as well as several further subdivisions and hybrid states. It is known that АМФ subtype populations vary between healthy individuals and patients with ALI/ARDS ${ }^{22}$, and by further investigating the cellular mechanisms by which this variation occurs it is likely we may discover new immunomodulatory targets that have the potential to mitigate the devastating effects of ALI/ARDS.

\section{Role of apoptosis in amplifying lung inflammatory responses and injury}

The main pathological features of ALI/ARDS include alveolar epithelial and endothelial cell death, neutrophil alveolitis, and destruction of epithelial capillary barriers, leading to vascular permeability and edema infiltration ${ }^{5,6}$. Furthermore, hyperoxic ventilation causes excess epithelial and endothelial cell death, exacerbates pre-existing lung injury and inflammation, and impairs alveolar fluid clearance ${ }^{23}$. Unchecked inflammation and cell death can promote tissue scarring, organ damage, and the development of autoimmune and chronic inflammatory disorders ${ }^{24}$, and impaired management of these insults can have severe long-term consequences ${ }^{25}$. Pro-apoptotic members of the tumor necrosis factor (TNF) family, Fas/FasL, are known to facilitate cell death, and increased concentrations of these mediators have been detected in bronchoalveolar lavage (BAL) samples of ARDS patients ${ }^{26,27}$. Instillation of Fas/FasL induced lung injury and inflammation ${ }^{28-30}$, while inhibition of Fas/FasL signaling or apoptosis attenuated lung injury in animals subjected to endotoxemia and mechanical ventilation ${ }^{29,30}$. This suggests that apoptosis, to some extent, affects the severity of ALI/ARDS progression and how well patients recover. Apoptotic cells may undergo secondary necrosis, or unprogrammed cell death, if not removed, leading to the release of endogenous ligands called damage-associated molecular patterns (DAMPs). High-mobility group box 1 (HMGB1) and other DAMPs resemble pathogen-associated molecular patterns (PAMPs) such as lipopolysaccharide (LPS $)^{19}$. These molecules exacerbate tissue inflammation and contribute to injury observed in ALI/ARDS, COPD, pneumonia, asthma, and pulmonary fibrosis $^{20}$. As expected, elevated HMGB1 levels were found in BAL obtained from peripheral airways of COPD patients ${ }^{31}$. Many patients at risk for ALI require medical attention well into the course of their initial systemic inflammatory illness, which means that blocking late-acting DAMPS may have greater clinical relevance than more rapidly released mediators. However, it appears that while ALI may resolve entirely in some patients, along with lung function recovery, other patients are more susceptible to the development of chronic disorders ${ }^{5,6}$.

Pyroptosis (pyro meaning "fever" or "fire") is a pro-inflammatory process of pre-programmed cell death distinct from apoptosis that results from activation of inflammatory proteases belonging to the caspase family, particularly caspase- $1,-4$, and $-5^{32}$. Inflammasomes are multiprotein complexes assembled by pattern recognition receptors (PRRs) in response to bacterial or viral PAMPs (e.g. LPS, bacterial flagella, viral DNA and RNA) and/or damaged host-cell derived DAMPs. These 
complexes recruit either caspase- 1 in the canonical inflammasome or caspase-4 and -5 in the non-canonical inflammasome ${ }^{33}$. Recruitment occurs either directly or indirectly through a caspase activation and recruitment domain (CARD) containing adapter protein called an apoptosis-associated speck-like protein containing a CARD (ASC) $)^{32}$. The activated caspase molecules serve two crucial functions: 1) proteolytic cleavage of perforation inducing protein Gasdermin D, which creates pores in the cell membrane to induce pyroptosis, and 2) cleavage of IL-1 $\beta$ and IL-18 into their active forms, which are then released by the pyroptotic cell and initiate a pro-inflammatory response $\mathrm{e}^{33,34}$. Furthermore, pyroptosis also promotes HMGB1 release, which as mentioned is highly expressed in inflammatory lung conditions $^{30,35}$. Pyroptosis works in accordance with apoptosis and is necessary for clearing pathogen-infected cells but when unrestricted can induce inflammation and can lead to organ failure, sepsis, and death ${ }^{34}$. In addition to pyroptosis, necrosis and necroptosis, ferroptosis, and autophagy-dependent cell death are all distinct from apoptosis in their activating stimuli $^{36-38}$ but nonetheless must be cleared from the alveolar space to prevent ALI/ARDS.

The phagocytic machinery that recognizes dead cells is regulated by signaling cascades and selective upregulation of anti-inflammatory genes coordinated by communication between apoptotic cells and phagocytes ${ }^{39}$. Engulfment of apoptotic cells by phagocytosis results in an abundance of reactive oxygen species (ROS), which stimulates macrophage apoptosis and inflammation persistence ${ }^{40,41}$. Regarding the role phagocytes play in mitigating ALI/ARDS progression, AMФs are recognized as initiators of pro-repair and pro-resolution processes necessary for restoring lung function following injury ${ }^{42}$. However, $\mathrm{AM} \Phi_{\mathrm{S}}$ also recruit inflammatory cells, produce pro-inflammatory cytokines, and mediate pro-fibrotic processes ${ }^{43}$. This functional dynamic makes $\mathrm{AM} \Phi$ s influential during both acute and resolution/recovery phases of lung injury ${ }^{44-46}$. Studies performed with serial BAL in humans with ARDS determined that increased AMФ numbers and matured cellular phenotype correlated with favorable clinical outcomes ${ }^{47-49}$. Currently, there is increasing evidence suggesting that macrophages, including resident $\mathrm{AM} \Phi_{\mathrm{S}}$ and recruited $\mathrm{AM} \Phi_{\mathrm{S}}$ derived from blood-circulating monocytes, are key regulators of ALI/ARDS pathogenesis ${ }^{50,51}$. These macrophages are phenotypically flexible and functionally heterogeneous, suggesting a key regulatory role in inflammation, injury, and repair throughout the course of ALI/ARDS ${ }^{52,53}$. This dual functionality AMФs play in both resolving and inducing inflammation demonstrates their unique and evasive role in maintaining lung homeostasis. Since these processes remain incompletely understood, further investigating the role of $\mathrm{AM} \Phi \mathrm{s}$ in ALI/ARDS pathogenesis is of clinical interest.

\section{Macrophage plasticity and lung injury resolution}

Phagocytes are classified as either "professional" or "non-professional". Professional phagocytes (e.g. monocytes, macrophages, neutrophils, etc.) are more abundant, secrete more cytokines, and display a wider range of phagocytic receptors $^{54}$ than their non-professional counterparts (e.g. epithelial cells, fibroblasts, etc.). They act as first responders to infection in the steady state by recognizing and removing bacteria and promote adaptive immunity by displaying antigens of digested pathogens for $\mathrm{T}$ and $\mathrm{B}$ cell recognition ${ }^{55}$. Phagocytes use PRRs including Toll-like receptors (TLRs), Nod-like receptors (NLRs), and RIG-I-like receptors (RLRs) to initiate phagocytosis or inflammatory signal transduction in response to microbial infection ${ }^{56,57}$. In the lung, macrophages comprise two subtypes: resident and recruited. The former and more prevalent population is found within the alveoli themselves, whereas the latter are derived from circulating monocytes recruited from the interstitial space to infection or injury sites $^{58}$. Resident $\mathrm{AM} \Phi$ s originate from progenitor yolk sac and fetal liver monocytes and become functionally active as soon as the first week after birth, continuously repopulating alveoli by auto-regeneration ${ }^{59}$. Resident $\mathrm{AM} \Phi_{\mathrm{S}}$ act as sentinels providing the first line of defense against respiratory infection and injury by clearing pathogens and debris ${ }^{60}$. However, severe enough insult can induce circulating (bone marrow-derived) monocyte migration from the periphery to the inflamed tissue, where they differentiate into monocyte-derived $\mathrm{AM} \Phi \mathrm{s}$ and initiate a pro-inflammatory and profibrotic response ${ }^{42,58}$.

$\mathrm{AM} \Phi_{\mathrm{s}}$ are particularly unique in their phenotypic plasticity, which refers to polarization between two distinct phenotypes depending on inflammatory microenvironment conditions ${ }^{61}$. Classically activated (M1) $\mathrm{AM} \Phi \mathrm{s}\left(\mathrm{AM} \Phi_{\mathrm{s}}{ }^{\mathrm{M} 1}\right)$ are cytotoxic and pro-inflammatory mediators that protect against pathogens by secreting pro-inflammatory cytokines and promoting Th1-type immunity ${ }^{62}$. Macrophage stimulation with interferon gamma (IFN $\gamma$ ) or TNF alpha (TNF- $\alpha$ ) in accordance with TLR agonists (e.g. LPS) induces M1 polarization. $\mathrm{AM} \Phi \mathrm{s}^{\mathrm{M} 1}$ produce cytotoxic and bactericidal ROS, reactive nitrogen species (RNS), and Th1 pro-inflammatory cytokines (e.g. IL-1, IL-6, IL-12, IL-23, and TNF- $\alpha$ ) and strongly express major histocompatibility complex (MHC) II, CD80, CD86, and iNOS surface markers ${ }^{63-65}$ (Figure 1A). The classically activated phenotype promotes inflammation and assists in opsonization, antibody-dependent cytotoxicity, and phagocyte-dependent defense functions. Enhanced clearance of dead cells performed by pro-resolution $A M \Phi_{\mathrm{s}}$ is a key process in tissue repair and resolution of $\mathrm{AM} \Phi^{\mathrm{M} 1}$-promoted inflammation. This process limits the production of pro-inflammatory cytokines (e.g. IFN $\gamma$, TNF- $\alpha$, IL-1, IL-6, IL-8, and LTB4) and increases the production of anti-inflammatory/reparative cytokines (e.g. M-CSF, IL-4, IL-10, IL-13, and transforming growth factor beta $[\mathrm{TGF}-\beta])^{43}$.

Alternatively activated (M2) $\mathrm{AM} \Phi_{\mathrm{S}} \quad\left(\mathrm{AM} \Phi_{\mathrm{s}}{ }^{\mathrm{M} 2}\right)$ are anti-inflammatory and promote tissue repair, fibrotic remodeling, and Th2-type immunity ${ }^{62,66}$. IL-4 and IL-13 play an important role in resolving inflammation and aid in lung regeneration by facilitating wound healing through suppression of inflammatory signaling (Figure 1B). Macrophage stimulation with IL-4 and IL-13 induces $\mathrm{AM} \Phi^{\mathrm{M} 2}$ polarization, leading to the 


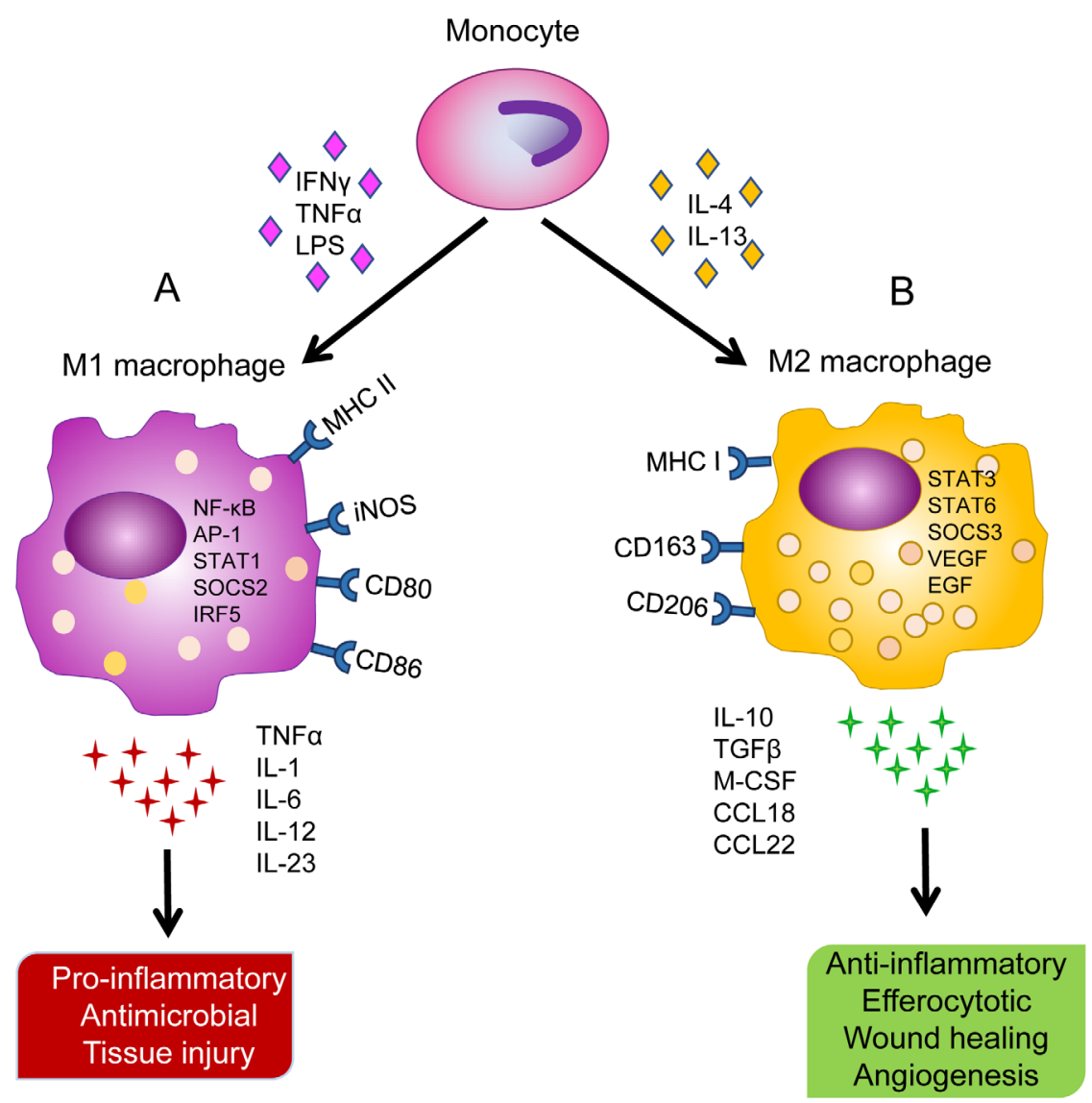

Figure 1. Different stimuli contributing to macrophage polarization along with differential surface markers, gene regulation, cytokine release, and physiological functions. A) Monocyte differentiation into classically activated alveolar macrophages $\left(A M \Phi^{\mathrm{M} 1}\right)$ upon stimulation with interferon gamma (IFN $\gamma$ ), tumor necrosis factor (TNF)- $\alpha$, and lipopolysaccharide (LPS). High expression of major histocompatibility complex $(\mathrm{MHC}) \mathrm{II}$, inducible nitric oxide synthase (iNOS), CD80, and CD86 surface markers. Upregulation of nuclear factor (NF)- $\mathrm{kB}$, activator protein 1 (AP-1), signal transducer and activator of transcription 1 (STAT1), suppressors of cytokine signaling 2 (SOCS2), and interferon regulatory factor 5 (IRF5). Release of TNF- $\alpha$, interleukin (IL)-1, IL-6, IL-12, and IL-23 cytokines leading to pro-inflammatory response, antimicrobial activity, and collateral tissue injury. B) Monocyte differentiation into alternatively activated alveolar macrophages (AM $\Phi^{\mathrm{M} 2}$ ) upon stimulation with IL-4 and IL-13. High expression of MHC I, CD163, and CD206 surface markers. Upregulation of STAT3, STAT6, SOCS3, vascular endothelial growth factor (VEGF) and epithelial growth factor (EGF). Release of IL-10, transforming growth factor (TGF)- $\beta$, macrophage colony-stimulating factor (M-CSF), CCL18, and CCL22 leading to anti-inflammatory response, efferocytosis, wound healing, and angiogenesis.

resolution of lung inflammation. АM $\Phi$ phenotypic changes are largely regulated by signal transducer and activator of transcription (STAT) transcription factors and suppressors of cytokine signaling (SOCS). STAT1/SOCS2 activation promotes the $\mathrm{AM} \Phi^{\mathrm{M} 1}$ phenotype while activation of STAT3/6 and SOCS3 promotes the $\mathrm{AM} \Phi^{\mathrm{M} 2}$ phenotype ${ }^{67}$. $\mathrm{AM} \Phi_{\mathrm{S}}^{\mathrm{M} 2}$ have been shown to resolve inflammation and initiate wound healing via the production of immunosuppressive cytokines (e.g. IL-10, TGF- $\beta$, CCL18, and CCL22) and angiogenesis mediators (e.g. VEGF and EGF) as well as express high levels of scavenger receptors (e.g. CD163 and $\mathrm{CD} 206)^{63-65} \cdot \mathrm{AM} \Phi_{\mathrm{s}}^{\mathrm{M} 2}$ also release immunosuppressive cytokines such as TGF- $\beta$, an inhibitor of NO production $^{63}$, and Arginase 1, which neutralizes reactive nitrogen intermediates ${ }^{50,68}$. $\mathrm{AM} \Phi \mathrm{s}^{\mathrm{M} 2}$ are highly heterogeneous, with several further subdivisions (i.e. M2a, M2b, and M2c) ${ }^{61,69}$. Distinct functional roles between $\mathrm{AM} \Phi \mathrm{s}^{\mathrm{M} 1}$ and $\mathrm{AM} \Phi \mathrm{s}^{\mathrm{M} 2}$ suggest that a counterbalance between their pro- and anti-inflammatory responsibilities must be maintained to promote lung homeostasis in response to infection and injury.

M1 and M2 classification is generally useful for describing functional differences in $\mathrm{AM} \Phi$ s throughout inflammatory processes but as a dichotomy neglects what appears to be a continuum of activation states that exists in vivo ${ }^{70}$. АMФs are constantly altered by extrinsic factors, with M1 and M2 phenotypes representing the extreme sides of an expression spectrum $^{71}$. In fact, most AMФs in the steady state display markers of both M1 and M2 phenotypes simultaneously, which is thought to allow quick switching between M1 and M2 functions ${ }^{72}$. Due to this flexible programming, АМФs 
have shown critical activity at all stages of alveolar repair and fibrosis and phenotype-dependent roles at distinct inflammatory and resolving phases. Transcriptomic datasets have provided immense amounts of information regarding macrophage integration and computation of local inflammatory signals, and understanding of $\mathrm{AM} \Phi$ transcriptional regulation can potentially be used to locate macrophage subset-specific therapeutic targets $^{73}$. Flexibility in AMФ programming and their adaptability to environmental changes suggests modulating these processes may provide therapeutics for ALI/ARDS patients.

\section{Neutrophil death contributions to ALI/ARDS}

Neutrophils are specialized leukocytes with life cycles ranging from only a few hours to days ${ }^{61}$. Due to these cells' short lifespans, neutrophil death is highly concerted and can occur via several mechanisms, including apoptosis, necrosis/necroptosis, and release of neutrophil extracellular traps (NETs). Neutrophil alveolitis and cell death contribute to inflammatory injury observed in ALI/ARDS patients, and their activating stimuli leading to efferocytosis influence the course of systemic inflammation. Distinct modes of neutrophil cell death have been implicated in several pathologies, including cancer, neurodegenerative disease, and autoimmune disorders ${ }^{74}$. Neutrophils are recruited as first responders to microbial infection to fight off invading pathogens, where they participate in phagocytosis, degranulation, ROS release, and NET release ${ }^{74}$. NETs are DNA-protein complexes released by neutrophils to neutralize pathogens in a process called NETosis. NETs are increasingly being investigated as contributors towards ALI/ARDS ${ }^{75,76}$. In vitro, in vivo, and clinical studies have confirmed that NETs promote ARDS inflammation by inducing $\mathrm{AM} \Phi^{\mathrm{M} 1}$ polarization and pro-inflammatory cytokine release, and increased M1 markers and decreased M2 markers were found in ARDS BAL fluid and lung tissue ${ }^{77}$. Furthermore, ARDS patients experience increased NET formation accompanied by decreased levels of AMФ engulfment of NETs and apoptotic neutrophils ${ }^{78}$. Neutralization of HMGB1 in the BAL fluid was shown to improve efferocytosis and NET clearance ${ }^{78}$, and engulfment of apoptotic neutrophils by phagocytes was found to promote anti-inflammatory signaling and homeostasis maintenance ${ }^{79}$. These results demonstrate that neutrophil contributions to ALI/ARDS are at least in part due to their influence on AMФ phenotype switching and in part due to the effectiveness of efferocytotic clearance following cell death.

\section{Efferocytosis and resolution of inflammatory lung injury}

Host defense and the protective roles leukocyte recruitment and phagocytosis play in acute inflammatory injury were first described in 1908 by Nobel Prize laureate Elie Metchnikoff ${ }^{80}$. However, much remains unclear as to how cellular communication facilitates apoptotic cell clearance and promotes homeostasis. As many as 150 billion cells, representing $0.4 \%$ of the body's cellular mass, are known to be turned over via apoptosis every day in the average adult ${ }^{81}$. Apoptotic cells are rarely observed, even in tissues with frequent cell turnover ${ }^{82}$, which suggests an efficient framework for clearing dead cells ${ }^{24}$.
Removal of apoptotic cells and debris by phagocytosis, a term coined "efferocytosis" by Henson, Gardai et al. (from the Latin effero meaning "to carry to the grave" or "to bury") ${ }^{83,84}$, appears to serve a crucial protective role against inflammatory injury. The process by which dead cells are identified, taken up, and disposed of by phagocytes is a highly regulated and concerted series of coordinated signaling (see below).

\section{Activation of efferocytosis machinery}

Efferocytotic signaling refers to phagocyte recruitment ("find me"), engulfment ("eat me"), and "post-engulfment" signals (Figure 2), and communication of these signals depends on phagocyte/apoptotic cell type, apoptotic stimuli, and stage of apoptosis ${ }^{24}$. Apoptotic cells release "find me" signals to initiate phagocytic uptake. Four different apoptotic "find me" signals have been identified: lysophosphatidylcholine (LPC), sphingosine-1-phosphate (S1P), nucleotides ATP and UTP, and CX3CL1 or fractalkine ${ }^{39}$. The first three mechanisms are caspase-3 dependent: 1) phosphatidylcholine is converted into LPC by apoptotic cells and subsequently released and recognized by $\mathrm{G} 2 \mathrm{~A}$ receptors on proximal macrophages ${ }^{85}$; 2) S1P, produced by the sphingosine kinase-catalyzed conversion of sphingosine, is released from apoptotic cells and recognized by $\mathrm{S} 1 \mathrm{P}$ receptors on macrophages ${ }^{86}$; and 3) apoptotic release of nucleotides ATP and UTP induces monocyte recruitment through recognition by phagocytic purinergic receptors. Furthermore, ATP and UTP receptor $\mathrm{P}_{2} \mathrm{Y}_{2}$ deficiency in mice showed a significant decrease in monocyte and macrophage recruitment, and nucleotide deficiency/P2 $\mathrm{Y}_{2}$ interference also resulted in inadequate clearance of apoptotic thymocytes ${ }^{87}$. In a caspase-3-independent mechanism, CX3CL1, or fractalkine, a membrane-associated protein released by apoptotic cells, binds to $\mathrm{CX} 3 \mathrm{C}$ motif chemokine receptor 1 (CX3CR1) on phagocytes to promote recruitment ${ }^{88}$. Additionally, upregulation of several solute carrier (SLC) proteins was found to take place at distinct "find-me" and "eat-me" stages of efferocytosis, suggesting a complex and incompletely understood regulatory system that warrants further investigation ${ }^{89}$. After recognition of these apoptotic "find-me" signals, phagocytes use additional cell signaling mechanisms to dispose of marked cells.

Apoptotic cells expose phosphatidylserine (Ptd-Ser) as an "eat-me" signal that can be recognized by several receptors (Figure 2). Remarkably, many molecules have been shown to act as Ptd-Ser receptors, including scavenger receptors (CD36 and SRA-1), $\alpha v \beta 3$ integrins, MerTK, Tim-4, BAI1, and stabilin-1 and $-2^{90}$. Many Ptd-Sers recognize multiple ligands and likely have roles other than apoptotic cell clearance ${ }^{91}$. Among the known Ptd-Ser receptors, Tim-4 and BAI1 and stabilin-2 directly bind to Ptd-Ser on apoptotic cells. Tim-4 is exclusively expressed on professional phagocytes ${ }^{92}$ and the main receptor mediating the phagocytosis of apoptotic cells ${ }^{93}$. Tim-4 is thought to act as a tethering receptor rather than directly transmitting engulfment signals $^{94}$, and Tim-4-dependent efferocytosis depends on the activation of integrins, focal adhesion kinase (FAK), and phosphoinositol-3 kinases ${ }^{93}$. Dysregulation of Tim- 4 expression has been found in autoimmune 
A

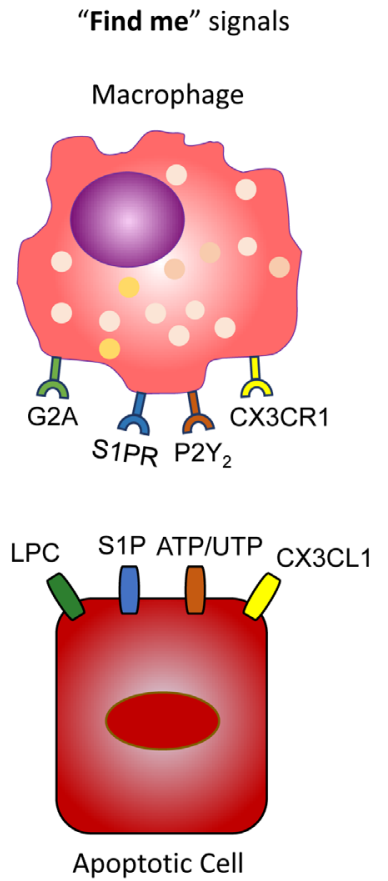

B

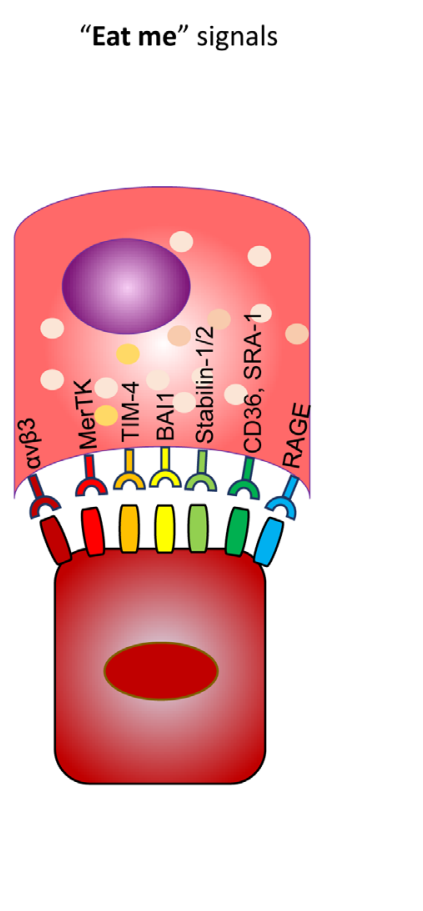

C

"Engulfment" signals

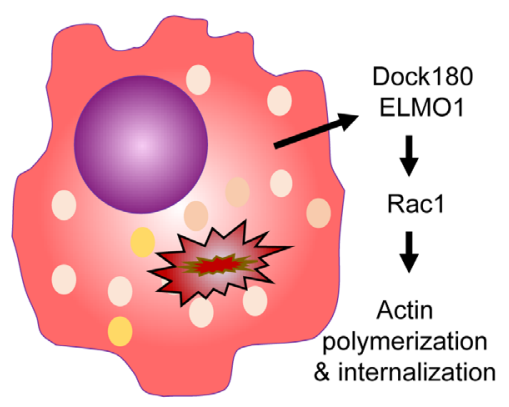

Figure 2. Efferocytosis broken down into "find me", "eat me", and engulfment signals. A) Apoptotic cells express "eat me" signals including lysophosphatidylcholine (LPC), sphingosine-1-phosphate (S1P), nucleotides ATP/UTP, and CX3CL1. These signals are recognized by G2A, S1PR, P2Y ${ }_{2}$, and CX3C motif chemokine receptor 1 (CX3CR1) receptors, respectively, by proximal macrophages. B) Recognized cells use Ptd-Ser receptors as an "eat me" signal to initiate engulfment, which can include $\alpha v \beta 3$ integrins, MerTK, TIM-4, BAI1, stabilin-1/2, CD36, SRA-1, and receptor for advanced glycation end products (RAGE). C) Following engulfment, dedicator of cytokinesis protein 1 (Dock180) and engulfment and cell motility protein 1 (ELMO1) act together as a guanine nucleotide exchange factor (GEF) to induce Rac1 GTPase, leading to cytoskeletal changes via actin polymerization followed by apoptotic cell internalization and phagolysosomal degradation.

conditions $^{95,96}$, and expression of Tim-4 decreased in response to oxidative stress ${ }^{97}$. Increased expression of Ptd-Ser receptor MerTK was found in airway macrophages of cigarette smokers and has been implicated in apoptotic cell buildup in the lungs of patients with $\mathrm{COPD}^{98}$. The MerTK-ERK pathway is also known to play a role in the resolution of inflammation ${ }^{99}$. Ptd-Ser receptor Axl is thought to play a role in apoptotic cell removal and was found to be expressed in mouse airway macrophages but not in interstitial macrophages or other lung leukocytes ${ }^{100}$. Receptor for advanced glycation end products (RAGE) is a recently characterized Ptd-Ser receptor highly expressed in AMФs. RAGE-deficient macrophages showed impaired phagocytic uptake of apoptotic thymocytes and neutrophils and led to increased alveolar accumulation of inflammatory cells following LPS stimulation ${ }^{101}$. Additionally, calreticulin (CRT) is thought to act as a Ptd-Ser-binding bridging molecule that can behave as an "eat-me" signal in cell death induced by endoplasmic reticulum (ER) stress. Protein kinase RNA-like ER kinase (PERK) phosphorylates eIF2 $\alpha$, promoting Bap31 cleavage and Bax activation in a caspase-8-dependent manner. CRT then moves from the ER to the Golgi apparatus and is displayed by apoptotic cells through SNARE-mediated exocytosis, where recognition of low-density lipoprotein receptor-related protein (CD91) by local phagocyte receptors leads to dead cell engulfment ${ }^{102}$. Hodge et al. have done extensive work investigating efferocytotic deficiency in COPD patients and have found reduced CD31, CD91, CD44, and CD71 expression and enhanced Ki-67 expression in the lungs of smokers compared with non-smokers ${ }^{103}$.

In contrast to "eat me" signals, "don't eat me" signals are displayed by healthy cells to prevent uptake by phagocytosis. Some of these signals have recently been characterized and are now of clinical interest as potential therapeutic targets in ALI/ARDS recovery. One of these "don't eat me" signals is integrin-associated protein (CD47), a surface membrane protein activated by activator protein 1 (AP-1) transcription factor c-Jun in fibroblasts, overexpression of which is associated with fibrotic injury ${ }^{104}$. Interestingly, antibody-mediated blockage of CD47 was found to be sufficient for reversing fibrosis and improving lung function in mice by increasing phagocytosis of profibrotic fibroblasts ${ }^{104}$. CD47 is an anti-phagocytic molecule that was found to be constitutively expressed in certain myeloid leukemias, indicating its role in assisting 
cancer cells by evading phagocytic recognition ${ }^{105}$. Preclinical data on anti-CD47 cancer therapy is promising ${ }^{106,107}$, and clinical trials have shown optimistic results in ameliorating tumor growth $^{108,109}$. Similarly, platelet endothelial cell adhesion molecule (CD31) is another surface membrane protein that plays a role in preventing engulfment by a repulsive CD31-CD31 interaction between healthy cells and phagocytes ${ }^{110}$. Many "don't eat me" signals with therapeutic potential for alleviating ALI/ARDS remain undiscovered or are not fully understood, so continuous investigation into these molecules is of clinical interest.

\section{Efferocytosis-induced intracellular signaling}

Following engulfment, phagocytic cytoskeletons must adapt to internalize dead cells. The Rho family of GTPases is an established regulatory factor in cellular movement and cytoskeletal changes $^{111}$ and is involved in virtually all actin-dependent processes including mobility, adhesion, and phagocytosis ${ }^{112}$. Rho GTPases use guanine nucleotide exchange factors (GEFs) to switch between inactive, or GDP-bound, and active, or GTP-bound, states ${ }^{112}$. One of these Rho family proteins highly expressed in macrophages ${ }^{113}$, Rac1, induces plasma membrane remodeling to allow phagosome internalization of dead cell particles by stimulating actin polymerization via the Rac-WAVE-Arp2/3 pathway ${ }^{114,115}$. Rac1 activation occurs when engulfment and cell motility protein 1 (ELMO1) and dedicator of cytokinesis protein 1 (Dock180) work coactively as a GEF for Rac1, promoting the cytoskeletal changes required for internalization ${ }^{116}$. Additionally, the intracellular domain of BAI1 was found to interact with ELMO1 and Dock180 GEF processes ${ }^{117}$. The role of ELMO1/Rac1 signaling in proper inflammatory functions is becoming particularly clear. For example, ELMO1 and Rac1 were found to be necessary for internalization processes and promoting inflammatory signaling, and inhibition of ELMO1 led to a sixfold decrease in Salmonella internalization ${ }^{118}$. Furthermore, ELMO1-deficient macrophages experienced reduction in TNF- $\alpha$ and monocyte chemoattractant protein 1 (MCP-1) release and in nuclear factor- $\kappa \mathrm{B}(\mathrm{NF}-\kappa \mathrm{B})$ activation and bacterial internalization ${ }^{117,118}$. Rac1 actin polymerization abilities likely involve interplay with ERK, FAK, AKT, and STAT6 as well ${ }^{119}$. Other members of the Rho GTPase family including Rac2, Rho, and Cdc42 showed involvement in macrophage efferocytosis ${ }^{120}$. Rho A is known to antagonize Rac1-mediated actin reorganization ${ }^{121,122}$, and its suppression assisted in apoptotic engulfment, whereas its overexpression inhibited phagocytic uptake ${ }^{123}$. Cigarette smoke has been found to inhibit efferocytosis through oxidantdependent activation of RhoA, but antioxidant supplementation prevented this effect, leading to the reversal of efferocytotic impairment ${ }^{124}$. RhoA was found to assist in actomyosin cytoskeleton contractions via the Rho-associated coiled-coil-containing protein kinase (ROCK) pathway, as well as in other processes including cell proliferation and migration ${ }^{125}$. C-type lectins like mannose-binding lectin (MBL) have also shown therapeutic potential. MBL promotes apoptotic cell uptake by increasing
Rac1/2/3 expression and is reduced in airways of COPD patients $^{126}$.

\section{Oxidant stress and efferocytosis impairment}

The accumulation of ROS inflicts intracellular destruction and initiates enhanced pro-inflammatory gene expression and cell death ${ }^{127}$. Engulfment of apoptotic cells creates an abundance of harmful ROS, and macrophage functions are heavily regulated by ROS production ${ }^{40,41}$. ROS are involved in macrophage polarization, functional and phenotypic regulation, and cell death, proliferation, and phagocytic ability ${ }^{40}$. ALI/ARDS patients exhibit significant oxidative stress on the lungs due to ventilation therapy-induced ROS accumulation ${ }^{128}$. Mitigation of excessive ROS and maintenance of intracellular redox homeostasis is crucial for ALI resolution. Cells have intrinsic antioxidant defense mechanisms for maintaining equilibrium in response to excess ROS generation ${ }^{129,130}$. A better understanding of the host defense response, such as antioxidant enzyme functions and deregulation in ARDS patients with and without hyperoxic ventilation, can help detect therapeutic targets that may prove useful for alleviating lung injury.

Hyperoxic stress and ROS accumulation can lead to functional changes in АМФs. For example, ROS production upregulates the expression of $\mathrm{AM} \Phi^{\mathrm{M} 1}$-associated pro-inflammatory transcription factors $\mathrm{AP}-1$ and $\mathrm{NF}-\kappa^{131}$. Additionally, TNF- $\alpha$ is known to induce activation of NF- $\mathrm{NB}$ and $\mathrm{AP}-1$, both of which in accordance produce inflammatory signals used by $А M \Phi s$ for communicating the inflammatory response to other cells in the lung $^{132}$. The $T N F-\alpha$ promoter region was found to contain both $\mathrm{NF}-\kappa \mathrm{B}$ and AP-1 binding sites, allowing for autoregulation ${ }^{133}$. Glucocorticoids inhibit NF- $\kappa \mathrm{B}$ and impair binding of AP-1, leading to a decrease in pro-inflammatory cytokine production, but administration of these drugs can detrimentally dampen the immune response to acute injury, making them oftentimes more harmful than useful to ALI/ARDS patients ${ }^{134}$. Another transcription factor, IFN regulatory factor 5 (IRF5), polarizes macrophages toward the pro-inflammatory phenotype (M1) 135 and was found in neutrophils and other myeloid cells ${ }^{136}$. Blockage of IRF5 is being investigated as a therapeutic measure for alleviating inflammation ${ }^{137}$ and promoting efferocytosis ${ }^{138}$. Another IFN-regulated transcription factor is STAT1, a member of the STAT protein family. STAT1 is known to activate quickly in response to IFNs and other pro-inflammatory cytokines and leads to mitochondrial stress, ROS accumulation, and apoptosis $^{139}$. STAT1 has been shown to modulate intracellular oxidative stress in macrophages through a p38 MAPK/STAT1/ ROS positive feedback loop ${ }^{140}$, and the absence of NADPH oxidase (NOX)-derived superoxide in $\mathrm{AM} \Phi_{\mathrm{S}}{ }^{\mathrm{M} 1}$ was shown to reduce both STAT1 and IRF5 expression as well as increase $\mathrm{AM} \Phi^{\mathrm{M} 2}$ transcriptional profile $\mathrm{e}^{141}$. ROS accumulation and inflammatory signaling are intimately related, and a better understanding of their genetic basis and how it relates to the AMФ protective role in efferocytosis can potentially reveal therapeutic targets to assist recovery in ALI/ARDS patients. 


\section{Activation of efferocytosis to accelerate lung injury resolution}

Imbalance between apoptotic cell death and efferocytosis can promote pathological conditions such as ALI/ARDS, COPD, cystic fibrosis, and asthma ${ }^{142,143}$, and impaired efferocytosis is implicated in complications associated with these conditions ${ }^{144}$. Inflammation in these lung diseases appears to worsen with inefficient removal of dead cells and debris, thus prolonging inflammation and impeding tissue repair. Delayed efferocytosis can cause apoptotic cells to undergo secondary necrosis and release DAMPs, which further promote inflammation by stimulating both innate and adaptive immune responses ${ }^{20}$. Efferocytotic impairment of airway macrophages leads to apoptotic and necrotic cell buildup, DAMPs release, upregulation of pro-inflammatory genes, and production of autoreactive $\mathrm{T}$ cells and B cells, all of which contribute to autoimmunity and chronic inflammation ${ }^{145}$. Prolonged inflammation can weaken resolution and potentially develop into fibrosis or chronic inflammatory conditions such as $\mathrm{COPD}^{145}$. Efferocytosis promotes lung homeostasis, facilitates resolution of apoptotic cell-induced inflammation $^{142}$, and corresponds with improved clinical outcomes in ALI/ARDS patients ${ }^{20}$.

Although defective clearance of apoptotic cells in the development of ALI/ARDS has been proposed $^{20,142}$ and oxidant stress affects efferocytotic ability of macrophages in vivo and in vitro ${ }^{146,147}$, the exact mechanisms contributing to dysfunctional efferocytosis are not completely understood. Further characterizing the molecular mechanisms used by $А M \Phi s$ to perform efferocytosis and resolve excessive inflammation in the lung, and how efficient functioning of these mechanisms can aid ALI/ARDS patients and other lung diseases in recovery, needs to be explored. It is possible that modulating efferocytosis can serve as a vital cellular strategy for managing the inflammatory response to injury and preventing development into chronic inflammatory disease ${ }^{81,82}$. Because of airway macrophages' tissue- and disease stage-specific roles, elucidation of their efferocytotic signal activation offers promising clinical potential for better prognosis in ALI/ARDS patients with fewer off-target effects.

In summary, efferocytosis plays crucial roles not only during development and in maintaining tissue homeostasis but also during tissue repair processes through a highly regulated and concerted network of signaling. Understanding this signaling by macrophages is of clinical interest to enhance lung tissue repair and restore respiratory functions following microbial and non-microbial insults. Defining whether there are distinct and specific set(s) of macrophages that exist in the lung that carry out efferocytosis in an injury- and disease-specific manner, and how and which efferocytosis machinery is activated or affected/impaired in acute clinical syndromes resulting in chronic lung diseases, may offer better clinical prognosis and therapeutic treatment strategies. Identifying both the activators and the effectors of efferocytosis that can be easily and preferentially targetable with fewer off-target effects, perhaps by administration of small molecules/drugs (protein or non-proteinous), is necessary to optimally accelerate lung tissue repair in ALI/ARDS patients and for improving clinical outcomes and reducing huge healthcare costs associated with microbial- and non-microbial-induced lung injury.

\section{Acknowledgements}

We thank Narsa Reddy (School of Medicine, Northwestern University, Chicago) for providing critical input on the manuscript.
1. Rubenfeld GD, Caldwell E, Peabody E, et al:: Incidence and outcomes of acute lung injury. N Engl J Med. 2005; 353(16): 1685-93. PubMed Abstract | Publisher Full Text | Faculty Opinions Recommendation

2. Young M, DiSilvio B, Rao S, et al:: Mechanical Ventilation in ARDS. Crit Care Nurs Q. 2019; 42(4): 392-9. PubMed Abstract | Publisher Full Text | Faculty Opinions Recommendation

3. Hunter JD: Ventilator associated pneumonia. BMJ. 2012; 344: e3325. PubMed Abstract | Publisher Full Text

4. Dietrich ES, Demmler M, Schulgen G, et al:: Nosocomial pneumonia: A cost-ofillness analysis. Infection. 2002; 30(2): 61-7. PubMed Abstract | Publisher Full Text

5. Huppert LA, Matthay MA, Ware LB: Pathogenesis of Acute Respiratory Distress Syndrome. Semin Respir Crit Care Med. 2019; 40(1): 31-9. PubMed Abstract | Publisher Full Text | Free Full Text | Faculty Opinions Recommendation

6. Matthay MA, Zemans RL, Zimmerman GA, et al.: Acute respiratory distress syndrome. Nat Rev Dis Primers. 2019; 5(1): 18 PubMed Abstract | Publisher Full Text | Free Full Text | Faculty Opinions Recommendation

7. Calfee CS, Delucchi KL, Sinha P, et al: Acute respiratory distress syndrome subphenotypes and differential response to simvastatin: Secondary analysis of a randomised controlled trial. Lancet Respir Med. 2018; 6(9): 691-8. PubMed Abstract | Publisher Full Text | Free Full Text | Faculty Opinions Recommendation

8. Krzak A, Pleva M, Napolitano LM: Nutrition therapy for ALI and ARDS. Crit Care Clin. 2011; 27(3): 647-59. PubMed Abstract | Publisher Full Text

9. Laffey JG, Matthay MA: Fifty Years of Research in ARDS. Cell-based Therapy for Acute Respiratory Distress Syndrome. Biology and Potential Therapeutic Value. Am J Respir Crit Care Med. 2017; 196(3): 266-73. PubMed Abstract | Publisher Full Text | Free Full Text

10. Matthay MA, Calfee CS, Zhuo H, et al:: Treatment with allogeneic mesenchymal stromal cells for moderate to severe acute respiratory distress syndrome (START study): A randomised phase 2a safety trial. Lancet Respir Med. 2019; 7(2): 154-62

PubMed Abstract | Publisher Full Text | Free Full Text | Faculty Opinions Recommendation

11. Plataki M, Lee YD, Rasmussen DL, et al:: Poloxamer 188 facilitates the repair of alveolus resident cells in ventilator-injured lungs. Am J Respir Crit Care Med. 2011; 184(8): 939-47.

PubMed Abstract | Publisher Full Text | Free Full Text

12. Lindsay $C D$ : Novel therapeutic strategies for acute lung injury induced by lung 
damaging agents: The potential role of growth factors as treatment options. Hum Exp Toxicol. 2011; 30(7): 701-24.

PubMed Abstract | Publisher Full Text

13. Albaiceta GM, Gutiérrez-Fernández A, Parra D, et al.: Lack of matrix metalloproteinase-9 worsens ventilator-induced lung injury. Am J Physiol Lung Cell Mol Physiol. 2008; 294(3): L535-43.

PubMed Abstract | Publisher Full Text | Faculty Opinions Recommendation

14. Albaiceta GM, Gutierrez-Fernández A, García-Prieto E, et al:: Absence or inhibition of matrix metalloproteinase-8 decreases ventilator-induced lung injury. Am J Respir Cell Mol Biol. 2010; 43(5): 555-63.

PubMed Abstract | Publisher Full Text

15. González-López A, Albaiceta GM: Repair after acute lung injury: Molecular mechanisms and therapeutic opportunities. Crit Care. 2012; 16(2): 209. PubMed Abstract | Publisher Full Text | Free Full Text

16. Lee JM, Kwon HJ, Bae SC, et al.: Lung tissue regeneration after induced injury in Runx3 KO mice. Cell Tissue Res. 2010; 341(3): 465-70. PubMed Abstract | Publisher Full Text

17. Martin TR, Frevert CW: Innate immunity in the lungs. Proc Am Thorac Soc. 2005; 2(5): 403-11.

PubMed Abstract | Publisher Full Text | Free Full Text

18. Fan EKY, Fan J: Regulation of alveolar macrophage death in acute lung inflammation. Respir Res. 2018; 19(1): 50

PubMed Abstract | Publisher Full Text | Free Full Text |

Faculty Opinions Recommendation

19. Roh JS, Sohn DH: Damage-Associated Molecular Patterns in Inflammatory Diseases. Immune Netw. 2018; 18(4): e27.

PubMed Abstract | Publisher Full Text | Free Full Text |

Faculty Opinions Recommendation

20. Schmidt EP, Tuder RM: Role of Apoptosis in Amplifying Inflammatory Responses in Lung Diseases. J Cell Death. 2010; 3: 41-53. PubMed Abstract | Free Full Text

21. Yurdagul A, Subramanian M, Wang X, et al:: Macrophage Metabolism of Apoptotic Cell-Derived Arginine Promotes Continual Efferocytosis and Resolution of Injury. Cell Metab. 2020; 31(3): 518-533.e10. PubMed Abstract | Publisher Full Text | Free Full Text | Faculty Opinions Recommendation

22. Morrell ED, Wiedeman A, Long SA, et al.: Cytometry TOF identifies alveolar macrophage subtypes in acute respiratory distress syndrome. JCl Insight. 2018; 3(10): e99281.

PubMed Abstract | Publisher Full Text | Free Full Text |

Faculty Opinions Recommendation

23. Matthay MA, Ware LB, Zimmerman GA: The acute respiratory distress syndrome. J Clin Invest. 2012; 122(8): 2731-40. PubMed Abstract | Publisher Full Text | Free Full Text

24. Elliott MR, Koster KM, Murphy PS: Efferocytosis Signaling in the Regulation of Macrophage Inflammatory Responses. J Immunol. 2017; 198(4): 1387-94. PubMed Abstract | Publisher Full Text | Free Full Text

25. Chiumello D, Coppola S, Froio S, et al:: What's Next After ARDS: Long-Term Outcomes. Respir Care. 2016; 61(5): 689-99.

PubMed Abstract | Publisher Full Text

26. Albertine KH, Soulier MF, Wang Z, et al.: Fas and Fas Ligand Are Up-Regulated in Pulmonary Edema Fluid and Lung Tissue of Patients with Acute Lung Injury and the Acute Respiratory Distress Syndrome. Am J Pathol. 2002; 161(5): 1783-96.

PubMed Abstract | Publisher Full Text | Free Full Text

27. Matute-Bello G, Liles WC, Steinberg KP, et al:: Soluble Fas ligand induces epithelial cell apoptosis in humans with acute lung injury (ARDS). $J$ Immunol. 1999; 163(4): 2217-25.

PubMed Abstract

28. Lopez AD, Avasarala S, Grewal S, et al.: Differential role of the Fas/Fas ligand apoptotic pathway in inflammation and lung fibrosis associated with reovirus $1 / \mathrm{L}$-induced bronchiolitis obliterans organizing pneumonia and acute respiratory distress syndrome. J Immunol. 2009; 183(12): 8244-57. PubMed Abstract | Publisher Full Text | Free Full Text | Faculty Opinions Recommendation

29. Kawasaki M, Kuwano K, Hagimoto N, et al.: Protection from Lethal Apoptosis in Lipopolysaccharide-Induced Acute Lung Injury in Mice by a Caspase Inhibitor. Am J Pathol. 2000; 157(2): 597-603.

PubMed Abstract | Publisher Full Text | Free Full Text

30. Le A, Damico R, Damarla M, et al.: Alveolar cell apoptosis is dependent on p38 MAP kinase-mediated activation of xanthine oxidoreductase in ventilatorinduced lung injury. J Appl Physiol (1985). 2008; 105(4): 1282-90. PubMed Abstract | Publisher Full Text | Free Full Text

31. Gangemi S, Casciaro M, Trapani G, et al:: Association between HMGB1 and COPD: A Systematic Review. Mediators Inflamm. 2015; 2015: 164913. PubMed Abstract | Publisher Full Text | Free Full Text

32. Vande Walle L, Lamkanfi M: Pyroptosis. Curr Biol. 2016; 26(13): R568-R572. PubMed Abstract | Publisher Full Text

33. $\mathrm{He} \mathrm{Wt}$, Wan H, Hu L, et al.: Gasdermin D is an executor of pyroptosis and required for interleukin-1ß secretion. Cell Res. 2015; 25(12): 1285-98. PubMed Abstract | Publisher Full Text | Free Full Text | Faculty Opinions Recommendation

34. Boada-Romero E, Martinez J, Heckmann BL, et al:: The clearance of dead cells by efferocytosis. Nat Rev Mol Cell Biol. 2020; 21(7): 398-414. PubMed Abstract | Publisher Full Text | Free Full Text

35. Frank D, Vince JE: Pyroptosis versus necroptosis: Similarities, differences, and crosstalk. Cell Death Differ. 2019; 26(1): 99-114.

PubMed Abstract | Publisher Full Text | Free Full Text

36. Newton K, Manning G: Necroptosis and Inflammation. Annu Rev Biochem. 2016; 85: 743-63.

PubMed Abstract | Publisher Full Text

37. Denton D, Kumar S: Autophagy-dependent cell death. Cell Death Differ. 2019; 26(4): 605-16.

PubMed Abstract | Publisher Full Text | Free Full Text

38. $\mathrm{Li}$ J, Cao F, Yin HL, et al.: Ferroptosis: Past, present and future. Cell Death Dis. 2020; 11(2): 88

PubMed Abstract | Publisher Full Text | Free Full Text |

Faculty Opinions Recommendation

39. Park SY, Kim IS: Engulfment signals and the phagocytic machinery for apoptotic cell clearance. Exp Mol Med. 2017; 49(5): e331.

PubMed Abstract | Publisher Full Text | Free Full Text

40. Tan HY, Wang N, Li S, et al:: The Reactive Oxygen Species in Macrophage Polarization: Reflecting Its Dual Role in Progression and Treatment of Human Diseases. Oxid Med Cell Longev. 2016; 2016: 2795090. PubMed Abstract | Publisher Full Text | Free Full Text

41. Brüne B, Dehne N, Grossmann N, et al:: Redox control of inflammation in macrophages. Antioxid Redox Signal. 2013; 19(6): 595-637. PubMed Abstract | Publisher Full Text | Free Full Text

42. Robb CT, Regan KH, Dorward DA, et al:: Key mechanisms governing resolution of lung inflammation. Semin Immunopathol. 2016; 38(4): 425-48. PubMed Abstract | Publisher Full Text | Free Full Text

43. Wynn TA, Vannella KM: Macrophages in Tissue Repair, Regeneration, and Fibrosis. Immunity. 2016; 44(3): 450-62. PubMed Abstract | Publisher Full Text | Free Full Text

44. Puttur F, Gregory LG, Lloyd CM: Airway macrophages as the guardians of tissue repair in the lung. Immunol Cell Biol. 2019; 97(3): 246-57. PubMed Abstract | Publisher Full Text | Faculty Opinions Recommendation

45. Yamada M, Fujino N, Ichinose M: Inflammatory responses in the initiation of lung repair and regeneration: Their role in stimulating lung resident stem cells. Inflamm Regen. 2016; 36: 15.

PubMed Abstract | Publisher Full Text | Free Full Text

46. Herold S, Mayer K, Lohmeyer J: Acute lung injury: How macrophages orchestrate resolution of inflammation and tissue repair. Front Immunol. 2011 2: 65 .

PubMed Abstract | Publisher Full Text | Free Full Text

47. Morrell ED, Bhatraju PK, Mikacenic CR, et al:: Alveolar Macrophage Transcriptional Programs Are Associated with Outcomes in Acute Respiratory Distress Syndrome. Am J Respir Crit Care Med. 2019; 200(6): 732-41. PubMed Abstract | Publisher Full Text | Free Full Text | Faculty Opinions Recommendation

48. Steinberg KP, Milberg JA, Martin TR, et al:: Evolution of bronchoalveolar cell populations in the adult respiratory distress syndrome. Am J Respir Crit Care Med. 1994; 150(1): 113-22.

PubMed Abstract | Publisher Full Text

49. Rosseau S, Hammerl P, Maus U, et al.: Phenotypic characterization of alveolar monocyte recruitment in acute respiratory distress syndrome. Am J Physiol Lung Cell Mol Physiol. 2000; 279(1): L25-35. PubMed Abstract | Publisher Full Text

50. Johnston LK, Rims CR, Gill SE, et al:: Pulmonary macrophage subpopulations in the induction and resolution of acute lung injury. Am J Respir Cell Mol Biol. 2012; 47(4): 417-26.

PubMed Abstract | Publisher Full Text | Free Full Text

51. Cliu M, Chen Y, Wang S, et al.: $\alpha$-Ketoglutarate Modulates Macrophage Polarization Through Regulation of PPAR $\gamma$ Transcription and mTORC1/ p70S6K Pathway to Ameliorate ALI/ARDS. Shock. 2020; 53(1): 103-13. PubMed Abstract | Publisher Full Text | Faculty Opinions Recommendation

52. A Aggarwal NR, King LS, D'Alessio FR: Diverse macrophage populations mediate acute lung inflammation and resolution. Am J Physiol Lung Cell Mol Physiol. 2014; 306(8): L709-25.

PubMed Abstract | Publisher Full Text | Free Full Text |

Faculty Opinions Recommendation

53. Thompson BT, Chambers RC, Liu KD: Acute Respiratory Distress Syndrome. N Engl J Med. 2017; 377(6): 562-72. PubMed Abstract | Publisher Full Text

54. Rabinovitch M: Professional and non-professional phagocytes: An introduction. Trends Cell Biol. 1995; 5(3): 85-7. PubMed Abstract | Publisher Full Text

55. Hirayama D, lida $\mathrm{T}$, Nakase $\mathrm{H}$ : The Phagocytic Function of 
Macrophage-Enforcing Innate Immunity and Tissue Homeostasis. Int J Mol Sci. 2017; 19(1): 92.

PubMed Abstract | Publisher Full Text | Free Full Text

56. Moretti J, Blander JM: Insights into phagocytosis-coupled activation of pattern recognition receptors and inflammasomes. Curr Opin Immunol. 2014; 26: $100-10$.

PubMed Abstract | Publisher Full Text | Free Full Text

57. CGuo HY, Zhang XC, Jia RY: Toll-Like Receptors and RIG-I-Like Receptors Play Important Roles in Resisting Flavivirus. J Immunol Res. 2018; 2018: 6106582.

PubMed Abstract | Publisher Full Text | Free Full Text |

Faculty Opinions Recommendation

58. McQuattie-Pimentel AC, Budinger GRS, Ballinger MN: Monocyte-derived Alveolar Macrophages: The Dark Side of Lung Repair? Am J Respir Cell Mol Biol. 2018; 58(1): 5-6.

PubMed Abstract | Publisher Full Text

59. Guilliams M, de Kleer I, Henri S, et al:: Alveolar macrophages develop from fetal monocytes that differentiate into long-lived cells in the first week of life via GM-CSF. J Exp Med. 2013; 210(10): 1977-92.

PubMed Abstract | Publisher Full Text | Free Full Tex

60. Allard B, Panariti A, Martin JG: Alveolar Macrophages in the Resolution of Inflammation, Tissue Repair, and Tolerance to Infection. Front Immunol. 2018; 9: 1777.

PubMed Abstract | Publisher Full Text | Free Full Text | Faculty Opinions Recommendation

61. Murray PJ, Allen JE, Biswas SK, et al:: Macrophage activation and polarization: Nomenclature and experimental guidelines. Immunity. 2014; 41(1): $14-20$.

PubMed Abstract | Publisher Full Text | Free Full Text |

Faculty Opinions Recommendation

62. Eapen MS, Hansbro PM, McAlinden K, et al:: Abnormal M1/M2 macrophage phenotype profiles in the small airway wall and lumen in smokers and chronic obstructive pulmonary disease (COPD). Sci Rep. 2017; 7(1): 13392 PubMed Abstract | Publisher Full Text | Free Full Text

63. Funes SC, Rios M, Escobar-Vera J, et al.: Implications of macrophage polarization in autoimmunity. Immunology. 2018; 154(2): 186-95. PubMed Abstract | Publisher Full Text | Free Full Text

64. Yao Y, Xu XH, Jin L: Macrophage Polarization in Physiological and Pathological Pregnancy. Front Immunol. 2019; 10: 792 PubMed Abstract | Publisher Full Text | Free Full Text

65. Yamasaki K, van Eeden SF: Lung Macrophage Phenotypes and Functional Responses: Role in the Pathogenesis of COPD. Int J Mol Sci. 2018; 19(2): 582. PubMed Abstract | Publisher Full Text | Free Full Text

66. Zhang L, Wang Y, Wu G, et al.: Macrophages: Friend or foe in idiopathic pulmonary fibrosis? Respir Res. 2018; 19(1): 170. PubMed Abstract | Publisher Full Text | Free Full Text | Faculty Opinions Recommendation

67. N Spence S, Fitzsimons A, Boyd CR, et al.: Suppressors of cytokine signaling 2 and 3 diametrically control macrophage polarization. Immunity. 2013; 38(1): 66-78.

PubMed Abstract | Publisher Full Text | Faculty Opinions Recommendation

68. Lawrence T, Natoli G: Transcriptional regulation of macrophage polarization: Enabling diversity with identity. Nat Rev Immunol. 2011; 11(11): 750-61.

PubMed Abstract | Publisher Full Text | Faculty Opinions Recommendation

69. Martinez FO, Gordon S: The M1 and M2 paradigm of macrophage activation: Time for reassessment. F1000Prime Rep. 2014; 6: 13. PubMed Abstract | Publisher Full Text | Free Full Tex

70. Atri C, Guerfali FZ, Laouini D: Role of Human Macrophage Polarization in Inflammation during Infectious Diseases. Int J Mol Sci. 2018; 19(6): 1801 PubMed Abstract | Publisher Full Text | Free Full Text

71. Mantovani A, Sica A, Sozzani S, et al:: The chemokine system in diverse forms of macrophage activation and polarization. Trends Immunol. 2004; 25(12): $677-86$.

PubMed Abstract | Publisher Full Text

72. Mitsi E, Kamng'ona R, Rylance J, et al.: Human alveolar macrophages predominately express combined classical M1 and M2 surface markers in steady state. Respir Res. 2018; 19(1): 66

PubMed Abstract | Publisher Full Text | Free Full Text |

Faculty Opinions Recommendation

73. Tejwani V, D'Alessio FR: The Transcriptional Signature in Alveolar Macrophages Dictates Acute Respiratory Distress Outcomes. Am J Respir Crit Care Med. 2019; 200(6): 656-7. PubMed Abstract | Publisher Full Text | Free Full Text

74. Brostjan C, Oehler R: The role of neutrophil death in chronic inflammation and cancer. Cell Death Discov. 2020; 6: 26. PubMed Abstract | Publisher Full Text | Free Full Text | Faculty Opinions Recommendation
75. $\mathrm{Li} \mathrm{H}$, Zhou X, Tan H, et al:: Neutrophil extracellular traps contribute to the pathogenesis of acid-aspiration-induced ALI/ARDS. Oncotarget. 2017; 9(2): 1772-84.

PubMed Abstract | Publisher Full Text | Free Full Text | Faculty Opinions Recommendation

76. Pedrazza L, Cunha AA, Luft C, et al.: Mesenchymal stem cells improves survival in LPS-induced acute lung injury acting through inhibition of NETs formation. J Cell Physiol. 2017; 232(12): 3552-64.

PubMed Abstract | Publisher Full Text

77. Song C, Li H, Li Y, et al:: NETs promote ALI/ARDS inflammation by regulating alveolar macrophage polarization. Exp Cell Res. 2019; 382(2): 111486.

PubMed Abstract | Publisher Full Text | Faculty Opinions Recommendation

78. C Grégoire M, Uhel F, Lesouhaitier M, et al.: Impaired efferocytosis and neutrophil extracellular trap clearance by macrophages in ARDS. Eur Respir J. 2018; 52(2): 1702590.

PubMed Abstract | Publisher Full Text | Faculty Opinions Recommendation

79. Greenlee-Wacker MC: Clearance of apoptotic neutrophils and resolution of inflammation. Immunol Rev. 2016; 273(1): 357-70.

PubMed Abstract | Publisher Full Text | Free Full Text

80. Gordon S: Elie Metchnikoff: Father of natural immunity. Eur J Immunol. 2008; 38(12): 3257-64.

PubMed Abstract | Publisher Full Text

81. Elliott MR, Ravichandran KS: The Dynamics of Apoptotic Cell Clearance. Dev Cell. 2016; 38(2): 147-60.

PubMed Abstract | Publisher Full Text | Free Full Text

82. Doran AC, Yurdagul A Jr, Tabas I: Efferocytosis in health and disease. Nat Rev Immunol. 2020; 20(4): 254-67.

PubMed Abstract | Publisher Full Text | Free Full Text |

Faculty Opinions Recommendation

83. Gardai SJ, McPhillips KA, Frasch SC, et al.: Cell-surface calreticulin initiates clearance of viable or apoptotic cells through trans-activation of LRP on the phagocyte. Cell. 2005; 123(2): 321-34.

PubMed Abstract | Publisher Full Text | Faculty Opinions Recommendation

84. deCathelineau AM, Henson PM: The final step in programmed cell death: Phagocytes carry apoptotic cells to the grave. Essays Biochem. 2003; 39 : 105-17.

PubMed Abstract | Publisher Full Text

85. Peter C, Waibel M, Radu CG, et al:: Migration to apoptotic "find-me" signals is mediated via the phagocyte receptor G2A. J Biol Chem. 2008; 283(9): 5296-305. PubMed Abstract | Publisher Full Text

86. Gude DR, Alvarez SE, Paugh SW, et al:: Apoptosis induces expression of sphingosine kinase 1 to release sphingosine-1-phosphate as a "come-and-get-me" signal. FASEB J. 2008; 22(8): 2629-38. PubMed Abstract | Publisher Full Text | Free Full Text

87. Elliott MR, Chekeni FB, Trampont PC, et al.: Nucleotides released by apoptotic cells act as a find-me signal to promote phagocytic clearance. Nature. 2009; 461(7261): 282-6.

PubMed Abstract | Publisher Full Text | Free Full Text

Faculty Opinions Recommendation

88. Truman LA, Ford CA, Pasikowska M, et al:: CX3CL1/fractalkine is released from apoptotic lymphocytes to stimulate macrophage chemotaxis. Blood. 2008; 112(13): 5026-36

PubMed Abstract | Publisher Full Text

89. Morioka S, Perry JSA, Raymond MH, et al.: Efferocytosis induces a nove SLC program to promote glucose uptake and lactate release. Nature. 2018 563(7733): 714-8

PubMed Abstract | Publisher Full Text | Free Full Text |

Faculty Opinions Recommendation

90. Ravichandran KS: Beginnings of a good apoptotic meal: The find-me and eat-me signaling pathways. Immunity. 2011; 35(4): 445-55. PubMed Abstract | Publisher Full Text | Free Full Text

91. Penberthy KK, Ravichandran KS: Apoptotic cell recognition receptors and scavenger receptors. Immunol Rev. 2016; 269(1): 44-59. PubMed Abstract | Publisher Full Text | Free Full Text

92. Kobayashi N, Karisola P, Peña-Cruz V, et al:: TIM-1 and TIM-4 glycoproteins bind phosphatidylserine and mediate uptake of apoptotic cells. Immunity. 2007; 27(6): 927-40.

PubMed Abstract | Publisher Full Text | Free Full Text

93. Flannagan RS, Canton J, Furuya W, et al.: The phosphatidylserine receptor TIM4 utilizes integrins as coreceptors to effect phagocytosis. Mol Biol Cell. 2014; 25(9): 1511-22.

PubMed Abstract | Publisher Full Text | Free Full Text

94. Park D, Hochreiter-Hufford A, Ravichandran KS: The phosphatidylserine receptor TIM-4 does not mediate direct signaling. Curr Biol. 2009; 19(4): 346-51. PubMed Abstract | Publisher Full Text

95. Abe $\mathrm{Y}, \mathrm{Kamachi} F$, Kawamoto T, et al: TIM-4 has dual function in the induction and effector phases of murine arthritis. J Immunol. 2013; 191(9): 4562-72. PubMed Abstract | Publisher Full Text 
96. Rodriguez-Manzanet R, Sanjuan MA, Wu HY, et al.: T and B cell hyperactivity and autoimmunity associated with niche-specific defects in apoptotic body clearance in TIM-4-deficient mice. Proc Natl Acad Sci U S A. 2010; 107(19): 8706-11.

PubMed Abstract | Publisher Full Text | Free Full Text

97. Fraser ST, Midwinter RG, Coupland LA, et al:: Heme oxygenase-1 deficiency alters erythroblastic island formation, steady-state erythropoiesis and red blood cell lifespan in mice. Haematologica. 2015; 100(5): 601-10. PubMed Abstract | Publisher Full Text | Free Full Text

98. Kazeros A, Harvey BG, Carolan BJ, et al.: Overexpression of apoptotic cell removal receptor MERTK in alveolar macrophages of cigarette smokers. Am J Respir Cell Mol Biol. 2008; 39(6): 747-57.

PubMed Abstract | Publisher Full Text | Free Full Text

99. Cai B, Kasikara C, Doran AC, et al.: MerTK signaling in macrophages promotes the synthesis of inflammation resolution mediators by suppressing CaMKII activity. Sci Signal. 2018; 11(549): eaar3721. PubMed Abstract | Publisher Full Text | Free Full Text | Faculty Opinions Recommendation

100. Fujimori T, Grabiec AM, Kaur M, et al:: The Axl receptor tyrosine kinase is a discriminator of macrophage function in the inflamed lung. Mucosal Immunol. 2015; 8(5): 1021-30.

PubMed Abstract | Publisher Full Text | Free Full Text

101. He M, Kubo H, Morimoto K, et al:: Receptor for advanced glycation end products binds to phosphatidylserine and assists in the clearance of apoptotic cells. EMBO Rep. 2011; 12(4): 358-64. PubMed Abstract | Publisher Full Text | Free Full Text | Faculty Opinions Recommendation

102. Panaretakis T, Kepp O, Brockmeier U, et al.: Mechanisms of pre-apoptotic calreticulin exposure in immunogenic cell death. EMBO J. 2009; 28(5): 578-90. PubMed Abstract | Publisher Full Text | Free Full Text

103. Hodge S, Hodge G, Ahern J, et al.: Smoking alters alveolar macrophage recognition and phagocytic ability: Implications in chronic obstructive pulmonary disease. Am J Respir Cell Mol Biol. 2007; 37(6): 748-55. PubMed Abstract | Publisher Full Text | Faculty Opinions Recommendation

104. C Cui L, Chen SY, Lerbs T, et al:: Activation of JUN in fibroblasts promotes pro-fibrotic programme and modulates protective immunity. Nat Commun. 2020; 11(1): 2795.

PubMed Abstract | Publisher Full Text | Free Full Text | Faculty Opinions Recommendation

105. Jaiswal S, Jamieson CHM, Pang WW, et al:: CD47 is upregulated on circulating hematopoietic stem cells and leukemia cells to avoid phagocytosis. Cell. 2009; 138(2): 271-85. PubMed Abstract | Publisher Full Text | Free Full Text | Faculty Opinions Recommendation

106. Liu J, Wang L, Zhao F, et al:: Pre-Clinical Development of a Humanized AntiCD47 Antibody with Anti-Cancer Therapeutic Potential. PLoS One. 2015; 10(9) e0137345.

PubMed Abstract | Publisher Full Text | Free Full Text

107. Willingham SB, Volkmer JP, Gentles AJ, et al:: The CD47-signal regulatory protein alpha (SIRPa) interaction is a therapeutic target for human solid tumors. Proc Natl Acad Sci U S A. 2012; 109(17): 6662-7. PubMed Abstract | Publisher Full Text | Free Full Text | Faculty Opinions Recommendation

108. Advani R, Flinn I, Popplewell L, et al:: CD47 Blockade by Hu5F9-G4 and Rituximab in Non-Hodgkin's Lymphoma. N Engl J Med. 2018; 379(18): 1711-21. PubMed Abstract | Publisher Full Text

109. S Sikic BI, Lakhani N, Patnaik A, et al.: First-in-Human, First-in-Class Phase I Trial of the Anti-CD47 Antibody Hu5F9-G4 in Patients With Advanced Cancers. $J$ Clin Oncol. 2019; 37(12): 946-53. PubMed Abstract | Publisher Full Text | Free Full Text | Faculty Opinions Recommendation

110. Brown S, Heinisch I, Ross E, et al.: Apoptosis disables CD31-mediated cell detachment from phagocytes promoting binding and engulfment. Nature. 2002; 418(6894): 200-3.

PubMed Abstract | Publisher Full Text | Faculty Opinions Recommendation

111. Hochreiter-Hufford A, Ravichandran KS: Clearing the dead: Apoptotic cell sensing, recognition, engulfment, and digestion. Cold Spring Harb Perspect Biol. 2013; 5(1): a008748. PubMed Abstract | Publisher Full Text | Free Full Text

112. Schmidt A, Hall A: Guanine nucleotide exchange factors for Rho GTPases: Turning on the switch. Genes Dev. 2002; 16(13): 1587-609. PubMed Abstract | Publisher Full Text

113. Fond AM, Ravichandran KS: Clearance of Dying Cells by Phagocytes: Mechanisms and Implications for Disease Pathogenesis. Adv Exp Med Biol. 2016; 930: 25-49. PubMed Abstract | Publisher Full Text | Free Full Text

114. Castellano $\mathrm{F}$, Montcourrier $\mathrm{P}$, Chavrier $\mathrm{P}$ : Membrane recruitment of Rac1 triggers phagocytosis. J Cell Sci. 2000; 113(Pt 17): 2955-61. PubMed Abstract
115. Molinie N, Gautreau A: The Arp2/3 Regulatory System and Its Deregulation in Cancer. Physiol Rev. 2018; 98(1): 215-38.

PubMed Abstract | Publisher Full Text | Faculty Opinions Recommendation

116. - Brugnera E, Haney L, Grimsley C, et al: Unconventional Rac-GEF activity is mediated through the Dock180-ELMO complex. Nat Cell Biol. 2002; 4(8): 574-82.

PubMed Abstract | Publisher Full Text | Faculty Opinions Recommendation

117. Park D, Tosello-Trampont AC, Elliott MR, et al:: BAl1 is an engulfment receptor for apoptotic cells upstream of the ELMO/Dock180/Rac module. Nature. 2007; 450(7168): 430-4.

PubMed Abstract | Publisher Full Text | Faculty Opinions Recommendation

118. Das S, Sarkar A, Choudhury SS, et al.: ELMO1 has an essential role in the internalization of Salmonella Typhimurium into enteric macrophages that impacts disease outcome. Cell Mol Gastroenterol Hepatol. 2015; 1(3): 311-24. PubMed Abstract | Publisher Full Text | Free Full Text

119. Nishi C, Yanagihashi Y, Segawa K, et al.: MERTK tyrosine kinase receptor together with TIM4 phosphatidylserine receptor mediates distinct signal transduction pathways for efferocytosis and cell proliferation. $J$ Biol Chem 2019; 294(18): 7221-30.

PubMed Abstract | Publisher Full Text | Free Full Text |

Faculty Opinions Recommendation

120. Hoppe AD, Swanson JA: Cdc42, Rac1, and Rac2 display distinct patterns of activation during phagocytosis. Mol Biol Cell. 2004; 15(8): 3509-19. PubMed Abstract | Publisher Full Text | Free Full Text | Faculty Opinions Recommendation

121. Schlam D, Bagshaw RD, Freeman SA, et al:: Phosphoinositide 3-kinase enables phagocytosis of large particles by terminating actin assembly through Rac/ Cdc42 GTPase-activating proteins. Nat Commun. 2015; 6: 8623. PubMed Abstract | Publisher Full Text | Free Full Text

122. Ikeda $\mathrm{Y}$, Kawai $\mathrm{K}$, Ikawa $\mathrm{A}$, et al.: Rac1 switching at the right time and location is essential for Fc $\gamma$ receptor-mediated phagosome formation. J Cell Sci. 2017; 130(15): 2530-40.

PubMed Abstract | Publisher Full Text

123. Tosello-Trampont AC, Nakada-Tsukui K, Ravichandran KS: Engulfment of apoptotic cells is negatively regulated by Rho-mediated signaling. $J$ Biol Chem. 2003; 278(50): 49911-9. PubMed Abstract | Publisher Full Text

124. Richens TR, Linderman DJ, Horstmann SA, et al:: Cigarette smoke impairs clearance of apoptotic cells through oxidant-dependent activation of RhoA. Am J Respir Crit Care Med. 2009; 179(11): 1011-21. PubMed Abstract | Publisher Full Text | Free Full Text

125. Uulian L, Olson MF: Rho-associated coiled-coil containing kinases (ROCK): Structure, regulation, and functions. Small GTPases. 2014; 5: e29846. PubMed Abstract | Publisher Full Text | Free Full Text | Faculty Opinions Recommendation

126. Hodge S, Matthews G, Dean MM, et al.: Therapeutic role for mannosebinding lectin in cigarette smoke-induced lung inflammation? Evidence from a murine model. Am J Respir Cell Mol Biol. 2010; 42(2): 235-42.

PubMed Abstract | Publisher Full Text | Faculty Opinions Recommendation

127. Mittal M, Siddiqui MR, Tran $\mathrm{K}$, et al.: Reactive oxygen species in inflammation and tissue injury. Antioxid Redox Signal. 2014; 20(7): 1126-67. PubMed Abstract | Publisher Full Text | Free Full Text

128. Reddy SP, Hassoun PM, Brower R: Redox imbalance and ventilator-induced lung injury. Antioxid Redox Signal. 2007; 9(11): 2003-12. PubMed Abstract | Publisher Full Text

129. Redza-Dutordoir M, Averill-Bates DA: Activation of apoptosis signalling pathways by reactive oxygen species. Biochim Biophys Acta. 2016; 1863(12): 2977-92.

PubMed Abstract | Publisher Full Text

130. Cho HY, Reddy SP, Kleeberger SR: Nrf2 defends the lung from oxidative stress. Antioxid Redox Signal. 2006; 8(1-2): 76-87. PubMed Abstract | Publisher Full Text

131. Pepperl S, Dörger M, Ringel F, et al.: Hyperoxia upregulates the NO pathway in alveolar macrophages in vitro: Role of AP-1 and NF-kappaB. Am J Physiol Lung Cell Mol Physiol. 2001; 280(5): L905-13. PubMed Abstract | Publisher Full Text

132. CLiu X, Yin S, Chen Y, et al.: LPS-induced proinflammatory cytokine expression in human airway epithelial cells and macrophages via NF- $\kappa B$ STAT3 or AP-1 activation. Mol Med Rep. 2018; 17(4): 5484-91. PubMed Abstract | Publisher Full Text | Faculty Opinions Recommendation

133. Liu $\mathrm{H}$, Sidiropoulos $\mathrm{P}$, Song $\mathrm{G}$, et al.: TNF-alpha gene expression in macrophages: Regulation by NF-kappa B is independent of c-Jun or C/EBP beta. J Immunol. 2000; 164(8): 4277-85. PubMed Abstract | Publisher Full Text

134. Chow CW, Herrera Abreu MT, Suzuki T, et al:: Oxidative stress and acute lung injury. Am J Respir Cell Mol Biol. 2003; 29(4): 427-31. PubMed Abstract | Publisher Full Text 
135. Krausgruber T, Blazek K, Smallie T, et al:: IRF5 promotes inflammatory macrophage polarization and $\mathrm{T}_{\mathrm{H}} 1-\mathrm{T}_{\mathrm{H}} 17$ responses. Nat Immunol. 2011; 12(3): 231-8. PubMed Abstract | Publisher Full Text | Faculty Opinions Recommendation

136. Weiss M, Byrne AJ, Blazek K, et al:: IRF5 controls both acute and chronic inflammation. Proc Natl Acad Sci U S A. 2015; 112(35): 11001-6. PubMed Abstract | Publisher Full Text | Free Full Text

137. Almuttaqi H, Udalova IA: Advances and challenges in targeting IRF5, a key regulator of inflammation. FEBS J. 2019; 286(9): 1624-37. PubMed Abstract | Publisher Full Text | Free Full Text | Faculty Opinions Recommendation

138. Seneviratne AN, Edsfeldt A, Cole JE, et al:: Interferon Regulatory Factor 5 Controls Necrotic Core Formation in Atherosclerotic Lesions by Impairing Efferocytosis. Circulation. 2017; 136(12): 1140-54 PubMed Abstract | Publisher Full Text | Free Full Text

139. Lee HJ, Oh YK, Rhee M, et al:: The role of STAT1/IRF-1 on synergistic ROS production and loss of mitochondrial transmembrane potential during hepatic cell death induced by LPS/d-GalN. J Mol Biol. 2007; 369(4): 967-84. PubMed Abstract | Publisher Full Text

140. Kim HS, Lee MS: Essential role of STAT1 in caspase-independent cell death of activated macrophages through the p38 mitogen-activated protein kinase/ STAT1/reactive oxygen species pathway. Mol Cell Biol. 2005; 25(15): 6821-33. PubMed Abstract | Publisher Full Text | Free Full Text

141. Padgett LE, Burg AR, Lei W, et al.: Loss of NADPH oxidase-derived superoxide skews macrophage phenotypes to delay type 1 diabetes. Diabetes. 2015; 64(3): 937-46.

PubMed Abstract | Publisher Full Text | Free Full Text

142. Yun JH, Henson PM, Tuder RM: Phagocytic clearance of apoptotic cells: Role in lung disease. Expert Rev Respir Med. 2008; 2(6): 753-65. PubMed Abstract | Publisher Full Text | Free Full Text

143. Vandivier RW, Henson PM, Douglas IS: Burying the dead: The impact of failed apoptotic cell removal (efferocytosis) on chronic inflammatory lung disease. Chest. 2006; 129(6): 1673-82.

PubMed Abstract | Publisher Full Text

144. McCubbrey AL, Curtis JL: Efferocytosis and lung disease. Chest. 2013; 143(6): $1750-7$.

PubMed Abstract | Publisher Full Text | Free Full Text

145. Sachet $M$, Liang $Y Y$, Oehler R: The immune response to secondary necrotic cells. Apoptosis. 2017; 22(10): 1189-204. PubMed Abstract | Publisher Full Text | Free Full Text

146. Raffin TA, Simon LM, Braun D, et al.: Impairment of phagocytosis by moderate hyperoxia (40 to 60 per cent oxygen) in lung macrophages. Lab Invest. 1980; 42(6): 622-6.

PubMed Abstract

147. Crowell RE, Hallin G, Heaphy E, et al:: Hyperoxic suppression of Fc-gamma receptor-mediated phagocytosis by isolated murine pulmonary macrophages. Am J Respir Cell Mol Biol. 1995; 12(2): 190-5.

PubMed Abstract | Publisher Full Text 